\title{
Global inequality and the Trump administration
}

\author{
Frederick W. Mayer ${ }^{1}$ and Nicola Phillips ${ }^{2 *}$ \\ ${ }^{1}$ Sanford School of Public Policy, Duke University and ${ }^{2}$ Department of Political Economy, King's College London \\ ${ }^{\star}$ Corresponding author. Email: nicola.phillips@kcl.ac.uk
}

(Received 13 September 2018; revised 5 November 2018; accepted 7 November 2018; first published online 2 January 2019)

\begin{abstract}
Since US President Donald J. Trump took office in January 2017, the future of the global economy has looked distinctly uncertain. This is not because a process of clear and purposeful change can be said to be underway. Instead, it is because of a pattern of piecemeal, inconsistent and contradictory fragments of policy, both domestic and international in orientation, in the arenas of trade, taxation, business relations, finance and banking, social and welfare provision, immigration, and environmental protection, whose cumulative significance remains unclear. The modest task of this essay is therefore to sketch the contours, patterns, inconsistencies and confusions presented by the Trump administration's approach to shaping the US economy and, by extension, the global economic order, and on that basis to offer an interpretation of its emerging implications for inequality both within the United States and across the world.
\end{abstract}

Keywords: Global Value Chains; Global Inequality; International Political Economy; Global Governance

Since US President Donald J. Trump took office in January 2017, the future of the global economy has looked distinctly uncertain. This is not because a process of clear and purposeful change can be said to be underway. Instead, it is because of a pattern of piecemeal, inconsistent, and contradictory fragments of policy, both domestic and international in orientation, in the arenas of trade, taxation, business relations, finance and banking, social and welfare provision, immigration, and environmental protection, whose cumulative significance remains unclear. The modest task of this short essay is therefore to sketch the contours, patterns, inconsistencies, and confusions presented by the Trump administration's approach to shaping the US economy and, by extension, the global economic order, and on that basis to offer an interpretation of its emerging implications for inequality both within the United States and across the world.

Our global economic context is what we have previously called the 'global value chain world': an historically novel form of industrial organisation that has crystallised since the 1970s, involving configurations of production and trade that are coordinated and controlled by transnational corporations. ${ }^{2}$ Global value chains (GVCs) reflect both the functional

\footnotetext{
${ }^{1}$ Frederick W. Mayer, Nicola Phillips, and Anne Posthuma (eds), 'The political economy of governance in a "global value chain world"', New Political Economy, 22:2 (2017).

${ }^{2}$ For a flavour of a voluminous literature, see Jeffrey Henderson, Peter Dicken, Martin Hess, Neil Coe, and Henry WaiChung Yeung, 'Global production networks and the analysis of economic development', Review of International Political Economy, 9:3 (2002), pp. 436-64; Gary Gereffi, John Humphrey, and Timothy Sturgeon, 'The governance of global value chains', Review of International Political Economy, 12:1 (2005), pp. 78-104; William Milberg and Deborah Winkler, Outsourcing Economics: Global Value Chains in Capitalist Development (Cambridge: Cambridge University Press, 2013); Gary Gereffi, 'Global value chains in a post-Washington consensus world', Review of International Political Economy, 21:1 (2014), pp. 9-37; Jeffrey Neilson, Bill Pritchard, and Henry Wai-Chung Yeung, 'Global value chains and global production networks in the changing international political economy: an introduction', Review of International Political Economy, 21:1 (2014), pp. 1-8; Mayer, Philllips, and Posthuma, 'Political economy of governance'.
} 
fragmentation of the production process - in which trade is no longer about the international exchange of final goods, but rather about trade in intermediate goods and services, or 'trade in tasks $^{3}$ - and its geographical fragmentation, as lead firms have outsourced and off-shored stages of the production process. To the extent that 80 per cent of global trade is now estimated to be coordinated within GVC structures, and one in five jobs worldwide are within GVC-based production, ${ }^{4}$ the Trump administration's approach to trade, tax, regulation, and other associated policy arenas inevitably carries both domestic and global repercussions of real consequence.

These repercussions include the forms of global inequality that are intrinsic to the GVC world, and which have for some time been the defining feature of the contemporary United States. ${ }^{5}$ Inequality in the GVC world, taking both a within- and between-country perspective, is a story above all about the growing global concentration of wealth, driven by the unprecedented creation and capture of value by the most powerful business and societal interests, through the mobilisation of massive asymmetries of market, social, and political power on which GVCs rest. ${ }^{6}$ The concentration of market power in a small number of giant lead firms in GVCs is readily visible across many sectors: retailing, office software and operating systems, smartphones, beer, commercial aircraft, soft drinks, credit card networks, automobile production, electronic goods, and many consumer goods. ${ }^{7}$ The consequence is the rise of monopolistic and monopsonistic market power in GVCs, where smaller firms and producers struggle for a share of value in intensely competitive environments, and workers and communities are often excluded from distributive gains.

As such, in early 2018, Oxfam's annual calculations revealed that 82 per cent of the wealth generated in 2017 went to the richest 1 per cent of the global population, while the 3.7 billion people who make up the poorest half of the world saw no increase in their wealth. They chart an annual increase in billionaire wealth by an average of 13 per cent since 2010, which exceeds annual average wage growth by six times over the same period, and an unprecedented increase in the number of billionaires between March 2016 and March $2017 .{ }^{8}$ Similarly in the United States, specifically, there has been a dramatic acceleration of inequality since 1980, such that the United States now has the highest income inequality among Western countries. Substantially all the gains in wealth in the thirty years from 1983 were captured by 20 per cent of US households, the wealth of the bottom 40 per cent declined in absolute terms, and we have seen essentially no change in median incomes, especially since the late 2000 s. $^{9}$ In 2017 , the salary of the average CEO of the 350 largest firms in the US increased by 17.6 per cent over 2016 levels, to $\$ 18.9$

\footnotetext{
${ }^{3}$ Gene Grossman and Esteban Rossi-Hansberg, 'Trading tasks: a simple theory of offshoring', American Economic Review, 98:5 (2008), pp. 1978-97.

${ }^{4}$ UNCTAD, World Investment Report 2013: Global Value Chains: Investment and Trade for Development (Geneva: United Nations Conference on Trade and Development, 2013); ILO, World Employment Social Outlook: The Changing Nature of Jobs (Geneva: International Labour Organization, 2015).

${ }^{5}$ For a tiny selection of recent contributions to the debate on inequality, see Thomas Piketty, Capital in the Twenty-First Century (Cambridge, MA: Belknap Press of Harvard University Press, 2014); Anthony B. Atkinson, Inequality: What Can Be Done? (Cambridge, MA: Harvard University Press, 2015); Edward N. Wolff, A Century of Wealth in America (Cambridge, MA: Harvard University Press, 2017); Peter Edward and Andy Sumner, 'Global poverty and inequality: Are the revised estimates open to an alternative interpretation?', Third World Quarterly, 39:3 (2018), pp. 487-509.

${ }^{6}$ Milberg and Winkler, Outsourcing Economics; Frederick W. Mayer and Nicola Phillips, 'Outsourcing governance: States and the politics of a "global value chain world"', New Political Economy (4 January 2017), pp. 1-16, available at: doi: 10.1080/ 13563467.2016.1273341; Nicola Phillips, 'Power and inequality in the global political economy', International Affairs (15 February 2017), pp. 1-16, available at: doi: 10.1093/ia/iix019.

${ }^{7}$ Milberg and Winkler, Outsourcing Economics, p. 114; Mayer and Phillips, 'Outsourcing governance', pp. 141-2.

${ }^{8}$ Oxfam, Reward Work, Not Wealth: To End the Inequality Crisis, We Must Build an Economy for Ordinary Working People, Not the Rich and Powerful, Oxfam Briefing Paper (January 2018), available at: \{https://d1tn3vj7xz9fdh.cloudfront.net/ s3fs-public/file_attachments/bp-reward-work-not-wealth-220118-en.pdf\} accessed 4 September 2018.

${ }^{9}$ Wolff, Century of Wealth.
} 
million, while the typical worker's wages increased by 0.3 per cent. ${ }^{10}$ According to a recent report by the United Nations Special Rapporteur on extreme poverty and human rights, the US has 25 per cent of the world's billionaires, while 40 million people live in poverty, 18.5 million in extreme poverty, and 5.3 million in conditions of absolute poverty comparable to 'Third World' conditions. The United States also has one of the lowest levels of intergenerational social mobility of any of the rich countries. ${ }^{11}$

States and governments have played a significant role not only in the creation of the GVC world, but also in enabling the dynamics of asymmetrical development with which it is associated. In previous work, we identified three areas of state governance that shape the context and impact of GVCs: facilitative governance; regulatory governance; and distributive governance. ${ }^{12}$ Briefly, facilitative governance was defined as the strategies and policies that support the formation and operation of GVCs, regulatory governance as 'either restraining or requiring behaviours of firms, often for the purpose of reducing negative externalities or other market failures', and distributive governance as the strategies and policies that seek directly to reshape the distribution of economic gains, often for the purpose of ameliorating grossly inequitable outcomes. Taken together, institutions of facilitative, regulatory, and distributive governance profoundly shape the contours of political-economic organisation and determine, in large measure, who wins and who loses in the global economy.

We propose to take this typology to our brief discussion here of the Trump administration's approach to economic policy, and its implications for inequality both within the United States and across the world.

\section{Facilitative governance}

Observers of the strategies of the United States (and other key neoliberal states) to facilitate global economic activity over the last thirty years have been able to point to more or less coherent package of trade, investment, intellectual property, and competition policy that has supported the emergence and consolidation of a GVC world. In this world, firms, not states, now play the major role in determining what will be produced where and on what terms, what will be traded internationally, and where, how, and by whom the value in the system is captured. ${ }^{13}$ Put slightly differently, global market engagement has shifted 'from a passive process involving the reaction of independent actors to market signals, as in international trade theories, to a set of industrial transformations constructed within system-wide dynamics of coordination and control by economic and non-economic actors'. ${ }^{14}$ The package has evolved over time, and it has also been the subject of intense contestation among states and sharp critiques by civil society, particularly in the wake of the economic crisis of the late 2000s. Nevertheless, the commitment to facilitation of the neoliberal order, along with the consolidation of the GVC world, largely endured through the Obama years.

The Trump administration, in contrast with the strategies of its predecessors, has pursued a fragmented, contradictory, and erratic approach to facilitative governance. This is most evident in relation to trade policy, where President Trump has communicated open hostility to the global

\footnotetext{
${ }^{10}$ Lawrence Mishel and Jessica Schieder, CEO Pay Remains High Relative to the Pay of Typical Workers and High-Wage Earners, Economic Policy Institute report (20 July 2017), available at: \{https://www.epi.org/publication/ceo-pay-remainshigh-relative-to-the-pay-of-typical-workers-and-high-wage-earners/\} accessed 4 September 2018.

${ }^{11}$ United Nations, Report of the Special Rapporteur on Extreme Poverty and Human Rights on his Mission to the United States of America, Note by the Secretariat, Human Rights Council (4 May 2018).

${ }^{12}$ Mayer and Phillips, 'Outsourcing governance'; Gary Gereffi and Frederick W. Mayer, 'Globalization and the demand for governance', in Gary Gereffi (ed.), The New Offshoring of Jobs and Global Development (Geneva: International Labour Organization, 2006), pp. 39-58.

${ }^{13}$ Mayer and Phillips, 'Outsourcing governance', p. 9.

${ }^{14}$ Neilson, Pritchard, and Yeung, 'Global value chains', p. 1.
} 
trade regime and shown an extraordinary willingness to provoke conflict with America's trading partners. A raft of new trade restrictions was announced in March 2018, including a 25 per cent tariff on steel imports and 10 per cent on aluminium, swiftly followed by extending temporary exemptions to most of the countries that would have been affected, and then in May further extensions to those exemptions for China, the EU, and Mexico. The prospect of 'trade war' with China escalated with China's retaliation on tariffs, and newspaper opinion pages in the US and around the world remain crammed with articles on the likelihood or otherwise of a full-scale global trade war, and the possible consequences thereof. ${ }^{15}$ Trump made renegotiating the tripartite North American Free Trade Agreement (NAFTA) a significant campaign issue, provoking tensions and destabilising relations with Mexico and Canada. Relations were not helped by the imposition of tariffs on both countries during the negotiations. Yet on 1 October 2018 the three countries announced that a new US-Mexico-Canada Agreement (USMCA) had been agreed in principle between the three partners. Notwithstanding the new name and a number of new provisions, most notably in the automotive sector, in the end the heart of the original NAFTA agreement remained intact.

How to make sense of this apparent abrupt departure from the established tenets of US trade policy? First, Trump's trade policy, while ostensibly about products such as steel, in fact revolves more around particular trading partners. The original justification for tariffs on steel and aluminium imports was national security - not a new rationale for protectionist measures in these sectors. This justification was quickly dismissed as unconvincing given the range of other products (lumber, milk, cars) that were drawn into the administration's tariff policy, the erratic nature of its roll-out, and the haphazard pattern of repeated exemptions from new tariff impositions, which undercuts any sense of policy consistency. ${ }^{16}$ A more plausible explanation relates to Trump's impetuous desire to appear confrontational vis-à-vis those countries that are most blamed by his 'base' for declining wages and the loss of jobs (China, the EU, Mexico), and by extension those that fit with an overall foreign policy rhetoric centring on the way in which certain countries and international organisations are thought to 'take advantage' of the United States. It is also hard not to see an element of personal spite in certain of the president's actions, particularly in the tiff over the NAFTA 'renegotiation' with Canada, hardly a natural villain for most Americans.

Second, and related, Trump's trade and tariff policy reflects a variegated approach to business interests, where certain sectors and industries are selected for increased protection and others are targeted with overtly hostile words and actions. Some sense can be made of the pattern in the context of the 'America First' rhetoric, where steel becomes the archetypal domestic industry associated with a nostalgic 'America vs globalisation' rhetoric that underpins the Trump administration's appeal to its base. As above, it is the political and electoral value of particular fragments of policy that lend some consistency to the picture, not any overall coherence within the policy framework itself. In other words, state governance is now being mobilised not in the general service of business interests in a GVC world, but rather in the interests of some sectors in connection with a nationalist rejection of the multilateral and regional trade order.

Elsewhere, Trump's relations with business have been volatile, with business leaders 'riding the tiger' in order to secure tax cuts (and, as discussed below, deregulation) while opposing Trump on trade and a range of other issues where he is seen to be acting against their interests. Resignations from bodies such as Trump's Manufacturing Council following the violent white nationalist rallies in Charlottesville, Virginia in August 2017, which Trump refused unequivocally to denounce, and from the National Economic Council following his announcement of steel and aluminium tariffs in early 2018, are examples of a tense relationship that has increasingly become reputationally toxic for many businesses and business leaders. Personal feuds with individuals such as Jeff Bezos, the

\footnotetext{
${ }^{15}$ See, for example, Dani Rodrik, 'How to avoid a trade war', Project Syndicate (10 July 2018); Neil Irwin, 'The economy can handle steel and aluminium tariffs: the real risk is erratic policy', New York Times (31 May 2018).

${ }^{16}$ Joseph E. Stiglitz, 'Trump's trade confusion', Project Syndicate (5 April 2018).
} 
founder of Amazon, again confound any generalised predictions that a billionaire's instincts would point to close government-business relations. Put together with an immigration policy that business leaders almost unanimously reject as contrary to their interests, we must conclude that the core state-business nexus at the heart of US facilitative governance is splintering and that the Trump administration will continue to follow a much less predictable pattern.

In tax policy, the Trump administration might appear to be more consistent in pursuing measures that facilitate global business. The tax legislation adopted in December 2017 reduced the corporate tax rate from 35 per cent to 21 per cent. Yet, in fact, this classic Republican tax reduction was coupled with a nationalistic effort to lessen the attractiveness to firms of keeping capital earned overseas out of the US tax system. Previously, income earned overseas was not subject to tax so long as the profits were not repatriated to the US - one of the pillars of facilitative governance in a GVC world. Under Trump's package all income is subject to tax, although the rate on income earned overseas is only half the standard corporate tax rate (at 10.5 per cent) and applicable only when profits represent more than 10 per cent of a firm's capital assets overseas. The tax reform also included a one-off repatriation tax provision as an incentive to draw profits back to the United States.

Although these more nationalistic aspects of the tax package would appear hostile to GVCs, in practice they are likely to do little to disrupt established patterns of facilitative governance vis-à-vis GVCs. Profits in GVCs are significantly financialised rather than associated with productive reinvestment. Offshoring is associated with a higher share of income going to profits, and financialisation of non-financial corporations is stronger in firms and sectors where offshoring is more intense (that is, in GVCs), as a result of pressure to maximise returns to shareholders and minimise tax exposure. GVCs are thus associated with 'the continued capacity of major industrialised countries to maintain profit growth within the confines of a financialised system'. ${ }^{17}$ William Milberg and Deborah Winkler show that, through the 2000s, firms that rely on 'sophisticated GVC arrangements' were among those returning the highest levels of share buybacks and dividends - key indicators of financialisation - including those in the IT hardware and software sectors (Cisco, Microsoft, Hewlett Packard, Dell, Intel), retail (Walmart, Home Depot) and consumer non-durables sector (Proctor \& Gamble). ${ }^{18}$

Trump's tax policies have done - and will do - little to change this. Evidence from previous onetime repatriation incentives show that firms are most likely to invest in share buybacks rather than job creation or research and development in the US economy, and there are instances of firms laying off workers once profits had been repatriated. ${ }^{19}$ Indeed, the 2017 tax cut prompted no less than $\$ 436.6$ billion of stock buybacks by US public companies in the second quarter of 2018 , following $\$ 242.1$ billion in the first quarter. ${ }^{20}$ Furthermore, maintaining overseas income tax rates at half the standard corporate tax rate may well incentivise firms to continue to invest overseas, rather than bringing manufacturing jobs back to the US. ${ }^{21}$ In any case, most of those few manufacturing jobs that might be 'brought back' would be filled not by human workers but by robots, and therefore most likely to be located not in the old Rust Belt but in high-tech centres. ${ }^{22}$

We have, therefore, a more muddled picture than previously in relation to facilitative governance under Trump, but one with significant distributive consequences pointing to an exacerbation of inequalities. By some estimates Trump's new tax law will reduce government tax

\footnotetext{
${ }^{17}$ Milberg and Winkler, Outsourcing Economics, pp. 14, 235.

${ }^{18}$ Ibid., p. 219.

${ }^{19}$ Wai Kit Choi, 'The Sisyphus's Rock of prosperity and disparity in the global economy: Giovanni Arrighi and Apple Inc.'s tax avoidance strategies from Obama to Trump', New Political Science, 40:2 (2018), pp. 285-308.

${ }^{20}$ Matt Egan, 'Tax cut triggers $\$ 437$ billion explosion of stock buybacks', CNN Money (10 July 2018), available at: \{https:// money.cnn.com/2018/07/10/investing/stock-buybacks-record-tax-cuts/index.html\} accessed 4 September 2018.

${ }^{21}$ Natalie Kitroeff, 'Tax law may send factories and jobs abroad, critics say', New York Times (8 January 2018); Choi, 'Sisyphus's Rock'.

${ }^{22}$ Stiglitz, 'Trump's trade confusion'.
} 
receipts by $\$ 136$ billion in 2018 , and increase the deficit by just below $\$ 1.5$ billion by 2028 , with clear immediate and knock-on distributive consequences for inequality as the budget for welfare provision shrinks. ${ }^{23}$ The impacts of Trump's trade policy on inequality remain to be seen, in part because the policy itself is so ambiguous, but also because it is not clear whether a retreat from free trade, were it to occur in earnest, would reduce inequality. Countries that are dependent on trade with the US in the multilateral system, and jobs that are associated with trade and GVCs, would be undermined by a global trade conflict and a retreat from the rules of the multilateral trading order that offer some element of protection to participants in the system. Increased US protectionism would generate some beneficiaries in other countries, as firms and exporters are presented with new opportunities as the US market becomes more closed and there is less competition from the US, and there would be some opportunities for countries able to replace China as a source of key imports for the United States. ${ }^{24}$ Yet these new opportunities are unlikely to be concentrated in poorer countries, or for those producers and workers that occupy the lower value tiers of GVCs. Trade in GVCs is associated strongly with social inequalities and inadequate protections for labour and the environment, but at the same time its dismantling could carry other kinds of distributive consequences that threaten some of the world's poorest workers and communities.

\section{Regulatory governance}

The approach to regulatory governance in the first 18 months of the Trump administration is much more consistent. Predictably, it has taken the form of a concerted drive towards deregulation, consistent with Trump's own viscerally anti-government instincts and the longstanding inclinations of the Republican political base. Alongside tax, it is this aspect of the emerging policy package that has been the major incentive for many businesses to support Trump, making a calculation that they can win from deregulation. At the same time, as indicated above, it involves 'riding the tiger', in relation to both managing the reputational costs of proximity to the Trump administration, and dealing with the policy directions which cut across their interests.

The deregulatory push has taken the form of both a significantly lower propensity to issue new federal regulations than the two preceding administrations, and an energetic programme of attempting to cancel, delay, and/or modify existing regulations. The list of domestic provisions in which Trump has attempted to intervene is dizzying, ranging from housing, education, finance and environment, to health, mining, power, telecommunications, transportation, labour, and agriculture. $^{25}$ The deregulatory drive has also involved challenging international regulatory mechanisms, most notably the Paris Climate Accord, and the generalised position of confrontation with international organisations features a fundamental hostility to the notion of binding international agreements - such as in relation to environmental or labour standards which would regulate the conduct of the US government or businesses, wherever located.

So far, however, the rhetoric has been more extreme than the substance. The administration was thwarted on some of its signature deregulatory initiatives, notably the dismantling of the healthcare system built around the Affordable Care Act, known as 'Obamacare'. There has been a pattern of slapdash hastiness in navigating the complex procedures surrounding repeal of federal regulations, which has meant that the administration has frequently run into difficulty with litigation in the latter stages of the process. Reflecting a pattern that has been characteristic across

\footnotetext{
${ }^{23}$ Erica Werner and Damian Paletta, 'Federal government will be unable to pay all bills sooner than expected, due to new tax law', Washington Post (31 January 2018); Kristina Peterson, 'Spending, deficit concerns arise with new tax law', Wall Street Journal (24 December 2017), cited in Choi, 'Sisyphus's Rock', p. 298.

${ }^{24}$ Rodrik, 'How to avoid'; Stiglitz, 'Trump's trade confusion'.

${ }^{25}$ See Brookings Institution, 'Tracking Deregulation in the Trump Era: Interactive Web Tool', available at: \{https://www. brookings.edu/interactives/tracking-deregulation-in-the-trump-era/\} accessed 4 September 2018).
} 
the government, at the Environmental Protection Agency (EPA), courts had struck down delays or repeals of regulations six times in the period to May $2018 .{ }^{26}$ Given the loss of expertise at the EPA arising from mass departures of public servants since Trump took office, the administration's prospects for advancing with its repeal agenda remain shaky.

At the same time, when blocked in its efforts to revoke regulations, the administration has often found 'work-arounds' by only selectively enforcing environmental, worker safety, consumer protection, and financial service regulations to which it is hostile. ${ }^{27}$ This pattern was evident in the attempt substantially to scale back the Dodd-Frank Act in May 2018 - legislation that was enacted in the context of the financial crisis of the late 2000s to regulate the financial services industry. While only minor revisions of the Act were in fact enacted, falling far short of what the banking and financial services industries had hoped for, the dominant interpretation was that the Trump administration would deregulate through the channels of enforcement - by not enforcing rules and by weakening institutions - rather than through more complicated legislative channels. As one observer, Aaron Klein of the Brookings Institution, was reported to have put it pithily, '[I] nstead of draining the swamp, the Trump administration is telling the alligators ... that the zookeepers are taking a nap. ${ }^{28}$

As with trade and tax policy, the Trump administration's approach to regulation is not going to help people at the bottom of the economic ladder in the United States. A cursory look at the nature of some of the regulatory changes - the efforts to dismantle protections for workers on such issues as overtime and tips, or protections for lower-income citizens against unscrupulous financial advisors and lenders - indicates that much of the deregulatory push disadvantages precisely the people whom Trump claims to champion. Similarly, Trump's attempts to roll back the Clean Power Plan and reactivate coal mining would lead to a deterioration in environmental and air quality and, as is ever the case, disproportionately harm lower-income people living in industrial areas and poor rural communities. ${ }^{29}$ While the repeal of Obamacare failed, other initiatives by the administration have reshaped the rules of the system and dismantled the healthcare protections afforded to many Americans, and increased the proportion of the population that are and are likely in the future to be uninsured. ${ }^{30}$

The same arguments apply outside the borders of the United States. The GVC world is already one in which regulation is under continual pressure, as firms seek both international and local conditions that lessen regulatory burdens on them, and indeed actively mobilise their political power to create those conditions. States have already 'outsourced' or 'delegated' substantial regulatory governance functions to the private sector. ${ }^{31}$ The approach of this US administration will likely accelerate this trend in which private companies have assumed responsibility for key welfare and social policy provisions that historically have been the preserve of national and local governments, both globally and domestically within the United States.

\footnotetext{
${ }^{26}$ Stuart Shapiro, 'Trump's deregulatory record doesn't include much actual deregulation', The Conversation (10 May 2018), citing Coral Davenport and Lisa Friedman, 'In his haste to roll back rules, Scott Pruitt, E.P.A. Chief, risks his agenda', New York Times (7 April 2018).

${ }^{27}$ Shapiro, 'Trump's deregulatory record'.

${ }^{28}$ Quoted in Erik Sherman, 'Scaling back Dodd-Frank is just the beginning of Trump's run on deregulation', CNBC News (24 May 2018).

${ }^{29}$ United Nations, Report of the Special Rapporteur.

${ }^{30}$ Paul Demko and Adam Cancryn, 'Trump's new health insurance rules expected to hurt Obamacare', Politico (19 June 2018); 'Trump pushes low-cost short-term healthcare plans critics call “junk”', The Guardian (1 August 2018).

${ }^{31}$ For a flavour of a vast literature, see Tim Bartley, 'Institutional emergence in an era of globalization: the rise of transnational private regulation of labor and environmental standards', American Journal of Sociology, 113:2 (2007), pp. 297351; David Vogel, 'The private regulation of global corporate conduct: Achievements and limitations', Business and Society, 49:1 (2010), pp. 68-87; Tim Büthe and Walter Mattli, The New Global Rulers: The Privatization of Regulation in the World Economy (Princeton, NJ: Princeton University Press, 2011); Richard Locke, The Promise and Limits of Private Power: Promoting Labor Standards in a Global Economy (Cambridge: Cambridge University Press, 2013); Mayer and Phillips, 'Outsourcing governance'.
} 


\section{Distributive governance}

We have touched a good deal on the distributive consequences of the administration's approach to facilitative and regulatory governance, arguing that Trump's tax policy and deregulation drive will likely exacerbate inequality without fundamentally altering the conditions that sustain GVCs and the concentration of wealth within them. A leitmotif in this discussion has been that, rhetoric aside, the economic policy approaches set out by the Trump administration in its first 18 months will not help its domestic 'base', and are in fact more likely to hurt it. Trade policy is included in this interpretation, as the effects of the trade conflicts that the administration is stoking will fall disproportionately on the struggling middle classes and lower-income social groups. These impacts would be felt particularly through the increases in consumer prices for basic and other goods that would result from retaliatory protectionism on the part of countries like China, given that lower-earning Americans spend a higher proportion of their income on imported goods. ${ }^{32}$ It would also be felt in the impact on US industries of retaliatory tariffs imposed by China and other countries, on products such as wine, pork, soybeans, cars, and others. Similarly, we have seen that while Trump's tax policies are, at least rhetorically, premised on bringing jobs back to the United States, they are unlikely to succeed in that objective.

In addition to the distributive consequences of the Trump administration's facilitative and regulatory measures, its approach to distributive governance cuts directly against the interests of lower- and middle-income Americans. Animating its approach is a minimalist conception of any role for government in redressing inequality. What follows from that is an effort to cut back on the full array of social programmes that at best only partially narrow the welfare gap between rich and poor in America. Perhaps the most salient example is the fierce hostility to the Affordable Care Act, including opposition to the expansion of Medicaid to cover more low-income Americans. The Trump administration is also seeking to limit food stamp eligibility, is cutting funding for public housing, opposes student loan forgiveness, and opposes increasing the minimum wage. Further, the administration has been hostile to labour rights, cutting funding for the National Labour Relations Board (NLRB), supporting 'right to work' measures, and, of course, appointing judges throughout the federal judiciary who share this orientation. Neil Gorsuch, an Associate Justice of the Supreme Court nominated by Trump, was recently a key vote in limiting the ability of public sector unions to operate.

Reflecting all of this, the UN Special Rapporteur on extreme poverty and human rights issued a condemnation of the dramatic change in distributive policy direction in the United States under Trump. According to his report, 'the new policies:

(a) provide unprecedentedly high tax breaks and financial windfalls to the very wealthy and the largest corporations;

(b) pay for these partly by reducing welfare benefits for the poor;

(c) undertake a radical programme of financial, environmental, health and safety deregulation that eliminates protections mainly benefitting the middle classes and the poor;

(d) seek to add over 20 million poor and middle class persons to the ranks of those without health insurance;

(e) restrict eligibility for many welfare benefits while increasing the obstacles required to be overcome by those eligible;

(f) dramatically increase spending on defence, while rejecting requested improvements in key veterans' benefits;

\footnotetext{
${ }^{32}$ Carla Norloff, 'Hegemony and inequality: Trump and the liberal playbook', International Affairs, 94:1 (2018), p. 67.
} 
(g) do not provide adequate additional funding to address an opioid crisis that is decimating parts of the country; and

(h) make no effort to tackle the structural racism that keeps a large percentage of non-whites in poverty and near poverty. ${ }^{33}$

While inequality has been a long-term characteristic of the US political economy, the actual and potential consequences of the Trump administration's approach to distributive governance are dramatic. Those on whom the impact is most likely to fall include - but are not limited to - those he commonly purports to be helping with his 'America First' rhetoric, and agenda will aggravate many of the socio-racial dimensions of existing inequalities. ${ }^{34}$ Moreover, US retrenchment from the social commitments that were, at least implicitly, a key element of the social compact underlying neoliberalism - what John Ruggie called 'embedded liberalism' many years ago ${ }^{35}$ - is also putting strains on other nations to follow suit. What happens in America rarely stays in America. These impacts are therefore not just domestic, and not just the result of domestic welfare policies, but the aggregate of the Trump administration's approach to distributive governance globally as well as locally, where trade, tax, regulatory, and other policies combine to augur a significant increase in inequality, with all of its human, moral, and economic consequences.

As a final word, it bears repeating that these policy directions under the Trump administration, as well as the contours of the GVC world itself, are subject to continual political contestation - by states, firms, civil society organisations, and citizens across the world. They do not reflect a new global consensus, despite generalisations about the new appeal of populism in the US, Europe, and elsewhere, and we should hesitate before seeing the short-term actions of one administration in the US, still early in its tenure, as long-term trends of structural significance for the global economy. To the extent that the persistence of extreme poverty and inequality are 'a political choice made by those in power', ${ }^{36}$ there is also, always, the possibility of a political alternative.

Frederick W. Mayer is Professor of Political Science at the Sanford School of Public Policy, Duke University. He can be contacted at: frederick.mayer@duke.edu

Nicola Phillips is Professor of Political Economy, Vice-President (Education), King's College London. She can be contacted at: nicola.phillips@kcl.ac.uk

\footnotetext{
${ }^{33}$ United Nations, Report of the Special Rapporteur, p. 4.

${ }^{34}$ Norloff, 'Hegemony and inequality'.

${ }^{35}$ John Ruggie, 'International regimes, transactions, and change: Embedded liberalism in the postwar economic order', International Organization, 36:2 (1982), pp. 379-415.

${ }^{36}$ United Nations, Report of the Special Rapporteur, p. 7.
}

Cite this article: Mayer, F. W. and Phillips, N. 2018. Global inequality and the Trump administration. Review of International Studies 45: 502-510, doi:10.1017/S0260210518000517 